\title{
Musikkvideoer til besvær
}

Musikkvideoformatet har de senere årene for alvor gjort sitt inntog i Midtøsten. Til noens glede, men også til manges forferdelse. Og som så ofte når underholdningsindustrien er involvert, dreier det seg også denne gangen mest om sex.

Av Jan Juchelka, høgskolelektor i arabisk på Forsvarets skolesenter.

Setter man seg til å zappe gjennom parabolen i Egypt, er det umiddelbart påfallende hvor stor del av sendetiden i Tv som går til musikkvideoer. Ikke bare er det mengder av kanaler som for eksempel Rotana, Mazzika og Melody Hits som utelukkende sender musikkvideoer døgnet rundt, men også andre private underholdningskanaler som Dream Tv og statlige Nile Tv fyller på med musikkvideoer mellom programmene. Nå er det ikke nødvendigvis noen direkte forbindelse mellom hvor mye musikk som sendes og hvor populært det er å se på. Musikkvideoer er gratis sendefyll for kanaler i et presset marked, finansiert av musikkprodusenter og mobiltelefontjenester. Tekstmeldingene som ruller over skjermen, reklamerer for selskapene, og ringetoner selges. Musikkprodusentene bruker videoene til å skape superstjerner som igjen øker deres inntekter gjennom salg av CD-ene, og til å kunne forlange høyere honorar for konsertopptredener. ${ }^{\mathrm{I}}$ Det er imidlertid ingen tvil om at folk i Egypt også ser på videoene. Med mindre det er en viktig fotballkamp eller noe helt utenom det vanlige som skjer i Midtøsten, så er det som regel musikkvideoer som ruller i bakgrunnen både på kafeen og i hjemmet.

Musikkvideoene har de siste årene I08 endret seg. De er blitt mer dristige, og en stadig større andel av dem spiller på erotiske strenger. Ikke før har pressen kommet seg av det ene musikkvideosjokket og fordømt "pornoklippet" som det ofte blir kalt, skrevet side opp og side ned, så slippes en ny video, og det moralske forfallet når nye bunnivåer. I de siste årene har musikkvideoene vært et yndet tema for fordømmelse i Egypt, og parlamentet brukte i perioden 2003-2004 visstnok nesten like mye tid på å diskutere et eventuelt forbud mot at videoene til en viss egyptisk popartist med navn Ruby skulle forbys fra statlig TV, som på politiske saker som egentlig stod på agendaen. ${ }^{2}$

I denne artikkelen vil jeg se litt nærmere på selve fenomenet, se på holdningene som er kommet fram i pressen og forsøke å plassere disse i en større kulturdebatt i Egypt og den arabiske verdenen.

\section{Langt over streken}

"Pornoklipp"-kontroversen i Egypt begynte så smått i 2002 da videoen til libanesiske Nancy Agrams låt "Akhasmak ah, asibak la" (“Å krangle med deg, ок, men forlate deg, aldri”) ble sluppet. Videoen vakte oppsikt på grunn av de erotiske innslagene og ble raskt stemplet som pornografisk. Låten ble en landeplage, og Nancy Agram ble 
superstjerne over natten. Videoen er fortsatt å se på arabiske satellittkanaler. Nancy Agram ble kanskje den første arabiske musikkvideostjernen. Mens stjerner også før spilte inn musikkvideoer, var det heretter videoene som skapte stjernene. Siden den gang har det gått slag i slag, og listen over kvinnelige popstjerner som man mener går langt over streken for hva som er moralsk akseptabelt, blir lengre og lengre. I begynnelsen var det utelukkende libanesiske kvinnelige popstjerner som så åpenlyst spilte på erotikk i videoene sine, men allerede året etter ble ånden sluppet ut av flasken og rabalderet var i gang igjen da Ruby som første egyptiske artist, brøt tabuet med videoen "Enta 'aref leh" (“Ja, du vet hvorfor").

Etter henne kan det se ut til å ha blitt en trend. Nye "sangerinner" som de færreste har hørt om og som ofte kommer rett fra magedans- og nattklubbmiljøene, lager videoer som tilsynelatende har lite annet for seg enn å tjene noen raske slanter. Navn som Pussy Samir, Nagla' og Maria sjokkerer gang på gang med videoer som blir sett på som vulgære og smakløse. For mange fortoner dette seg som den reneste flodbølgen. En flodbølge som fullstendig har snudd opp ned på hva som kreves for å slå igjennom, og som truer med en total marginalisering av hva som måtte være igjen av "respektable artister". Er man ikke så heldig med utseendet eller ikke kan synge, er det bare å ta av seg noen flere plagg enn den forrige artisten og danse enda mer forførende og vulgært.

\section{Hat-/ kjærlighetsforhold}

Amina Khayri skriver at folk sitter i timevis foran skjermen og ser på musikkvideoer, og uansett hvor mye de kritiserer det de ser, havner de på sofaen igjen og vil ha mer. Jentene følger nøye med på nye trender innen mote og sminke hos sangerne, uten at det tilsynelatende kolliderer med deres overbevisning om at musikkvideoene representerer en synd, og at sangerne, i motsetning til dem selv som går med hijab, kommer til helvete. Også guttene ser på, sannsynligvis av andre årsaker. Men også de er overbevist om at sangernes skjebne er i helvete. ${ }^{3}$ Det er et utbredt hat/kjærlighetsforhold til videoene. De blir fordømt av de aller fleste, men er likevel ettertraktede og blir sett på.

Stjernene blir trendsettere, og media følger nøye med på stjernenes "new look” og plastiske operasjoner. Skjønnhetssalonger i Egypt gjør det bedre enn aldri før, og plastiske operasjoner er minst like utbredt, om ikke mer, enn i Vesten. Hos frisøren kan man nå gå og be om å få en Nancy Agrameller Rubyklipp.

\section{Symbol på alt som er galt}

For den politiske opposisjonen er videoene blitt et symbol på alt som er galt i Egypt. "I Egypt er til og med musikksmaken rammet av forfall”, skriver opposisjonsavisen alGhad. "Epoken (underforstått Mubaraks tid) som har brakt politisk, sosialt, økonomisk og moralsk forfall har nå også nådd sangen, og respektabel sang har ikke lenger noe å stille opp med mot "pornosangerinnene' og de nakne kroppene". ${ }^{4}$

I en annen opposisjonsavis - al-Wafd, den 28. oktober 2004 - skriver Gamal Badawi at arabiske regimer støtter denne formen for media. ${ }^{5}$ Målet skal være å sørge for at araberne ikke våkner opp av sin dype søvn og slik holder seg unna andre og mer kritiske problemer. Om det her dreier seg om en bevisst konspirasjon er usikkert, 
men resultatet er i hvert fall at regimene slipper brysom oppmerksomhet rundt sine politiske fallitter. Istedenfor går folk hjem og drukner sine sorger i billig underholdning.

Al-Ghad skriver sarkastisk at selv om arabisk enhet har mislyktes totalt politisk, så har den lykkes gjennom videoklippene. Kairo, Riyad og Beirut, som tidligere har ligget i bitter konkurranse med hverandre, har kommet fram til en ny fellesformel for suksess: Saudiarabisk kapital uten erfaring på kulturfronten, vulgære egyptiske melodier og tekster og libanesiske skjønnheter som knapt kan synge. Det er det folk vil ha. ${ }^{6}$

I motsetning til hva mange tror, så flettes de arabiske landene for tiden nærmere sammen igjen, og det ikke minst gjennom populærkulturen som vises på de felles panarabiske satellittkanalene. Dessverre for nasjonalistenes del ser det imidlertid ut til at panarabismens mer høybårne ideer har måttet vike for en ny og hyperkommersiell "hubba-bubba-panarabisme".

\section{Den nye verdensordenen}

Mange ser på musikkvideoene først og fremst som et tegn på vestlig kulturell dominans og som en undergraving av "arabiske” verdier. Ashraf Galal skriver i alHayat 20. april 2004 at musikkvideoene "har en total mangel på arabisk identitet og positive verdier, og at de inneholder en klar aksept for vestlige verdier hvor det ikke er noe rom for arabisk miljø. I tillegg opphever de alt av høyere betydninger og verdier." Den palestinske dikteren Tamim Barghouti skriver at "Videoene er fulle av halvnakne, flotte damer og rike, kjekke og unge menn, som kjører kabrioleter og flørter med hverandre, med europeiske grønne scener og overdådige villaer i bakgrunnen. På denne måten forsøker videoene å få arabisk ungdom til å ønske å bli noe de ikke kan, et speilbilde av sine tidligere koloniherrer." Slik blir musikkvideoene en form for kulturimperialisme og et utrykk for vestlig kulturell dominans.

Reaksjonene er ofte nært forbundet med en globaliseringsfrykt som er utbredt i Midtøsten, en frykt for å miste kontroll over egen økonomi, utenrikspolitikk og samfunnsmoral. Denne globaliseringsfrykten florerer i skjæringspunktet mellom den arabiske nasjonalismen som frigjøringsideologi og det mange oppfatter som en kampanje for å underkaste Midtøsten en vestlig agenda, som går Israels ærend på tvers av arabiske nasjonale interesser. Sett i lys av dette oppleves musikkvideoenes verdensbilde som fullstendig løsrevet fra alle relevante realiteter. Al-Messeri skriver at dette aldri var tydeligere enn da Sheikh Ahmed Yassin ble drept. Hele den arabiske verdenen var i sorg og sinne, mens lettkledde kvinner fortsatte å sprette rundt på skjermen som om ingenting var hendt.' Her kommer vi inn på en argumentasjon som ofte er å finne igjen i forskjellige varianter, og som mange mener nesten har fungert som en uskreven regel i Egypt og andre arabiske land. Det blir ofte hevdet at sittende eliter bruker eller unnskylder seg med at blant annet demokrati og et generelt åpnere samfunn først kan komme etter at konflikten med Israel har blitt løst. Nasjonal frigjøring - kampen mot Israel - går dermed på bekostning av individuell frigjøring. Men i klimaet etter Bagdads fall, som av mange blir sett på som enda mer

Den libanesiske sangeren Nancy Agram er kontroversiell. 


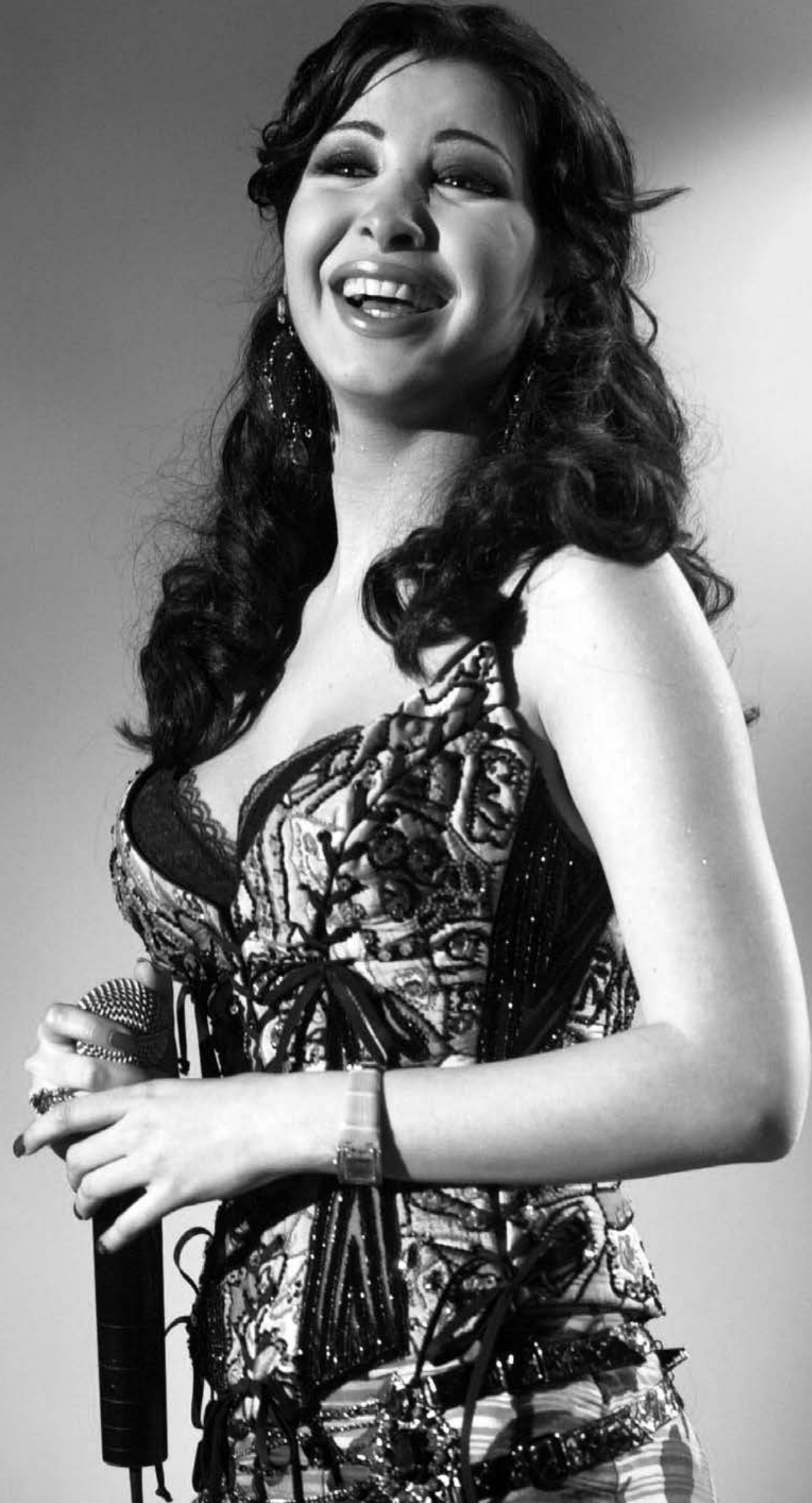


katastrofalt enn nederlaget i ig67, og med forvirringen og den utbredte følelsen av nederlag og fallitt som det har skapt, settes det nå oftere spørsmålstegn ved om individuelle friheter fortsatt burde være underlagt høyere verdier som stat, religion og identitet.

Kanskje videoene slik er et tegn på at $\mathrm{i}$ hvert fall noen i Midtøsten etter hvert har funnet sin plass i den nye verdensordenen. Men selv om noen tilsynelatende har funnet seg til rette, så sitter millioner av andre i sjokktilstand og er ikke lenger i stand til å begripe hva som foregår.

\section{Men hva betyr musikkvideoene?}

Er videoene til de såkalte "pornoklipp-sangerinnene" virkelig fullstendig løsrevet fra enhver lokal kulturell kontekst, og er det virkelig bare en ren kommersiell utnyttelse av kvinnekroppen for økonomisk vinning? Humphrey Davies skriver i motsetning til hva man vanligvis får høre, at "Nancy Agram er det beste som har hendt arabisk populærkultur siden shawarmaen kom. ${ }^{\text {o } \mathrm{I}}$ videoene "Akhasmak ah" og "Ah wa nuss" giør hun narr av machomenn som hun lar falle av syklene og slåss med hverandre bare på grunn av en vakker kvinne. På den måten tar hun med humor og glimt i øyet et oppgjør med gamle machoholdninger. Og er ikke magedansen - som i en eller annen form er fremtredende $i$ de fleste videoene - en integrert del av Egypts kultur? Som kunstform har den vært med i egyptisk underholdningsindustri siden dens spede begynnelse, og Humphrey mener at folk så på magedansscenene $\mathrm{i}$ gamle egyptiske svart-hvitt filmer av akkurat de samme grunnene som at folk ser på musikkvideoer i dag. Så hva er problemet?

Al-Messeri skriver at "magedansen, med sine erotiske dimensjoner er en del av våre kulturelle tradisjoner." ${ }^{\text {"I }}$ Men han mener også at den alltid har vært forbeholdt en slags uglesett parallellverden klart atskilt fra folks dagligliv. Man kunne se et show på en nattklubb, for så å vende tilbake til den normale verdenen. Også på film har magedansen som regel blitt fremført på nattklubber eller i brylluper, og magedanserinnene har stort sett hatt rollen som umoralske kvinner og har dermed støttet opp om bildet av hva som er moralsk riktig. I følge al-Messari har flere av musikkvideoene fjernet denne grensen: En normalisering av det unormale, som han kaller det. Eksempler her er nettopp Nancy Agrams "Akhasmak ah", der hun går kledd i helt vanlige baladi-klær, slik kvinner fra lavere klasser gjerne går, på en kafé der det sitter helt vanlige folk og spiller backgammon og kort. Hun vasker gulv, danser og vrikker seg mellom kafégjestene, og sender et og annet bedårende blikk mot kameraet. Et annet eksempel er Rubys video "Enta 'aref leh" der hun uanfektet vandrer giennom gatene kledd i magedanskostyme for senere å skifte til vanlige klær og danse videre. Hun danser på en amatørmessig måte, slik jenter gjør hjemme. Slik bryter også hun den usynlige barrieren mellom sfæren der magedans vises og dagliglivet.

Kvinners stilling i det arabiske samfunnet er et kontroversielt tema, og det blir ikke mindre kontroversielt av at problematikken settes inn i en debatt om vestliggiøring. Kvinner blir ofte sett på som selve bærebjelken i samfunnet. Den berømte egyptiske predikanten Amr Khaled sier på sin bestselgerkassett om slørets dyder at dersom kvinnen "faller", så faller hele samfunnet. Det er derfor, mener han, at islams fiender begynner med kvin- 
nen når de vil skade islam. Hvem beærer kvinnen mest? Islam som med sløret beskytter kvinnens bluferdighet som et skjell beskytter sin perle eller Vesten som stiller henne til skue for alt og alle og utnytter kroppen kommersielt, spør han retorisk på samme kassett. ${ }^{12}$ I hvilken grad det er en synd å se på musikkvideoer og hva musikkvideoene gjør med menn, kvinner og ekteskaplige forhold blir heftig diskutert i debattprogrammer.

Også sekulære feminister i Egypt har problemer med debatten der de føler seg presset mellom to onder - kommersiell utnytting av kvinnekroppen og religiøs konservatisme. Feministaktivisten Amal Abd al-Hadi frykter at musikkvideoene kan føre til en ny konservativ reaksjon. ${ }^{13}$ Utenfor den arabiske verdenen har man derimot ofte et mer optimistisk syn. Charles Paul Freund fester for eksempel sin lit til at musikkvideoene vil bringe den arabiske verden til en liberal modernitet. ${ }^{14}$

\section{Hva kultur burde være}

Dagens musikkvideokontrovers kan også ses på som en del av en større kulturdebatt i Egypt. Denne dreier seg om selve forholdet mellom kunst og samfunnet, massemedia og staten, det utenlandske og det autentiske. ${ }^{15}$ Kultureliten i Egypt mener ofte at kunstens rolle burde være oppbyggende, opplysende og ideologisk. Den må ha et mål og en mening. Den må ha noe å formidle. Amr Khaled uttrykker denne holdningen når han sier at det vi trenger er kunst og kultur som inspirerer ungdommen til arbeid, utvikling og produksjon. ${ }^{16}$ Musikkvideoene blir derimot sett på som utelukkende å dreie seg om penger. De blir ansett som meningsløse og vulgære og som nok et trinn på den nedadgående spi- ralen av moralsk, kulturell og politisk forfall.

Egypts musikalske storhetstid anses ofte for å være perioden etter revolusjonen i 1952. Dette var en periode da massemedia, film og musikk ble kanalisert for å fremme

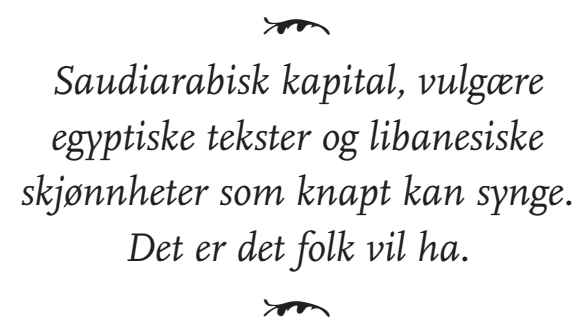

revolusjonens ideer og utrykke befolkningens håp om å bygge et moderne Egypt. Mye dreide seg om å heve befolkningens kulturelle nivå og smak. Denne uttrykksformen ble kanonisert giennom superstjerner som Umm Kalthoum og Abd alHalim Hafez og andre som med staten og kultureliten i ryggen, nærmest monopoliserte scenen i tjue år, og kvalitet blir fortsatt ofte målt opp mot de samme standardene.

Nederlaget i 1967 ble begynnelsen på slutten for denne uttrykksformen. Hele regimet ble diskreditert. Musikkformen som hadde tilhørt perioden levde en stund videre på de gamle stjernene, men etter hvert gikk de bort og ble ikke erstattet. Man mistet kontrollen, og nye media utenfor statsstyret skapte nye uttrykksformer. På mange måte kan det som nå skjer med musikkvideoene gjennom satellittrevolusjonen, sammenlignes med musikkformene som dukket opp giennom kassettrevolusjonen på midten av syttitallet. Kassetter var, som parabolantenner i dag, tilgjengelig for alle og utenfor direkte statlig kontroll. Nye former for arbeiderklassemusikk (sha'bi) gjennom Ahmed 
Adawiyya og ungdomsmusikk (shababi) dukket siden opp på åttitallet. Også disse ble møtt med mye av den samme kritikken som musikkvideoene utsettes for i dag. Tekstene var vulgære og meningsløse, og også her dreide det seg visstnok bare om penger. Ahmed Adawiyya ble boikottet av offisielle medier i mange år, men det var

\section{De intellektuelle kjemper en kamp de} umulig kan vinne om fortsatt kontroll over hvilke verdier som skal voere viktige for ungdommen.

nettopp hans avstand fra "å heve folks kulturelle nivå-retorikken” som gjorde ham annerledes enn sangerne som ble støttet av kultureliten, og som gjorde ham så populær. Patricia Kubala spør om ikke Ruby og hennes likesinnede kanskje er dagens Adawiyya. ${ }^{17}$

Etter Adawiyya har det meste som har skjedd innen populær- og ungdomskultur blitt sett på som en stadig nedadgående spiral der alt som ikke faller i kulturelitens smak, men som ser ut til å slå an hos folk, blir stemplet som vulgært (habit). De intellektuelle elitene kjemper en kamp de umulig kan vinne - en kamp om fortsatt kontroll over hvilke verdier som skal være viktige for ungdommen. Det kan dermed se ut til at kultureliten havner mer og mer i utakt med hva folk vil ha, i hvert fall dersom vi går ut fra at det er en sammenheng mellom hva folk vil ha og hva som selger. For istedenfor å gå inn i seg selv og granske sine egne holdninger, isolerer kultureliten seg og skylder på at det er publikum som er håpløst forvirret og udannet. Dermed har man også i kulturlivet fått et gap mellom folk og elite, ikke ulikt det som allerede eksisterer i politikken mellom folket og makten.

\section{Motstrømninger}

Etter et kjapt blikk på musikkanalene på arabisk Tv kan man lett sitte igjen med inntrykket av at alt i musikkvideoindustrien bare dreier seg om å vise mest mulig hud og at det er det eneste som selger. Men ved nærmere ettersyn viser det seg ikke helt å stemme. Det er fortsatt rom for alfann al-hadif, som den mer sosialt oppbyggende formen for kulturelle utrykk kalles. På begynnelsen av al-Aqsaintifadaen kom det en lang rekke patriotiske sanger av kjente egyptiske sangere, blant annet Amr Diyab, som fikk mye sendetid. Også nylig under den siste libanonkrigen var flere av de kontroversielle sangerinnene raskt ute med patriotiske sanger til støtte for Libanon. Den egyptiske arbeiderklassesangeren Sha'aban Abd al-Rahim har også kastet seg inn på videomarkedet med sanger som kommenterer politiske hendelser - alt fra karikaturstriden, intifadaen og angrepet på Irak. Sha'aban er minst like kontroversiell som Nancy Agram, men av helt andre grunner. Og så har vi Sami Yusef, en britisk religiøs sanger av aserbajdjansk opprinnelse som synger religiøst oppbyggelige sanger og er blitt voldsomt populær blant unge muslimer av den hippe typen.

Det ser også ut til at musikkvideoindustrien og satellittkanalene er villige til å ta innover seg kritikken fra presse og publikum. En musikkvideo av den libanesiske sangerinnen Maria, der hun halvnaken danser oppi en bløtkake, vakte så mye protester at satellittkanalene tok den av luften 
etter bare to uker. Og videoene til tunisiske Najla' har blitt forbudt flere ganger etter press fra "The Egyptian Musician Association”. Et annet virkemiddel som ser ut til å bli brukt i kampen mot musikkvideoene, er å nekte popstjerner innreise i Egypt. Kanskje som følge av dette presset er det i det siste kommet flere videoer der tradisjonelle "familieverdier" er fremtredende. I 2005 dukket det for eksempel opp en video med en ny sanger, Haytham Sa'id som for første gang presenterte en jente i skaut på en egyptisk musikkvideo. Denne videoen var regissert av Sherif Sabri, samme mannen som står bak de beryktede videoene til Ruby.

Selv om ikke alle var overbegeistret for at man presenterte en "respektabel" jente med skaut i en "usømmelig” setting som musikkvideoer anses for å være, har disse likevel stort sett fått god mottakelse i pressen.

\section{Storm i et vannglass}

At eldre generasjoner er misfornøyde med hva ungdommen liker og at yngre generasjoners kulturelle utrykk blir stemplet som vulgære og meningsløse, er ikke noe nytt verken i Egypt eller andre steder. Det synes ikke som om publikum er så enfoldige som kultureliten ofte vil ha det til. For å slå igjennom på mer permanent basis og ikke bare skape en skandale, trengs mer enn bare å vise hud og kunne danse erotisk. Nancy Agram har ikke bare utseende, men også humor og glimt i øyet, og Sami Yusuf er et eksempel på at også islam selger i musikkvideoformatet. Kontroversen vil nok rase videre en stund. Frykten for hvordan musikkvideoene kan komme til å forderve både samfunn og individ er utbredt. Troen på eller frykten for at musikkvideoer skal kunne revolusjonere samfunnet er i beste fall en overdrivelse. Noen seksuell revolusjon i Midtøsten på grunn av et par musikkvideoer blir det neppe.

\section{- $f$ •}

I Armbrust, Walter ; "What would Sayyid Qutb Say?” i твS, vol. I, 2005 .

2 "All I favor of Ruby" i Egypt Today, juli 2004.

3 Khayri, Amina; "Arab Video Clips Flirt with Desires of Egyptian Youth" i TBs, op. cit.

4 “al-ikti'ab yusaytar 'ala nujoum al-tarab bi sabab mutribat al-burnou" i al-Ghad, 5. oktober 2005.

5 Referert fra Amina Khayri i твs, op. cit.

6 “Jami'a Amr Mousa baqat zikra tayyiba" i al-Ghad, september/oktober 2005 .

7 Referert fra Hammond, Andrew; "Pop Culture Arab World!” ABC-Clio, Santa Barbara (2005).

8 Referert fra Walter Armbrust: "What Would Sayyid Qutb Say?” твS, op. cit.

9 al-Messeri, Abd al-Wahhab; "Ruby and the chequered heart” i al-Ahram Weekly, I7. mars 2005.

Io Davies, Humphrey; "Video Venom Must Stop!" i www.tbsjournal.com.

II al-Messeri, Abd al-Wahhab, op. cit.

I2 Khaled, Amr, u. d. al-Hijab (preken utgitt på kassett).

I3 "Sexy stars push limits in Egypt" i news.bbc.uk.

I4 Freund, Charles paul; Look Who's Rocking the Casbah." I www.reason.com, juni 2003.

I5 Kubala, Patricia; "The Other Face of the Video Clip" i TBS, op. cit.

I6 Khaled, Amr; "Culture, The Distinguishing Feature of a People" i твs, op. cit.

I7 Kubala, Patricia; "The Other Face of the Video Clip" i твs, op. cit. 